\title{
Article
}

\section{In Vitro and In Vivo Regulation of SRD5A mRNA Expression of Supercritical Carbon Dioxide Extract from Asparagus racemosus Willd. Root as Anti-Sebum and Pore-Minimizing Active Ingredients}

\author{
Warintorn Ruksiriwanich ${ }^{1,2,3, * \mathbb{D}}$, Chiranan Khantham ${ }^{1} \mathbb{D}$, Pichchapa Linsaenkart ${ }^{1}$, Tanakarn Chaitep ${ }^{1}$, \\ Pensak Jantrawut 1,2,3, Chuda Chittasupho ${ }^{1,2}{ }^{(D}$, Pornchai Rachtanapun ${ }^{3,4}\left(\mathbb{D}\right.$, Kittisak Jantanasakulwong ${ }^{3,4}$, \\ Yuthana Phimolsiripol ${ }^{3,4}$ (D), Sarana Rose Sommano ${ }^{2}$ (D) Chaiwat Arjin ${ }^{5}$ (D), Houda Berrada ${ }^{6}$, \\ Francisco J. Barba ${ }^{6}$ (D) and Korawan Sringarm $2,3,5$ (D)
}

check for

updates

Citation: Ruksiriwanich, W.; Khantham, C.; Linsaenkart, P.; Chaitep, T.; Jantrawut, P.; Chittasupho, C.; Rachtanapun, P.; Jantanasakulwong, K.; Phimolsiripol, Y.; Sommano, S.R.; et al. In Vitro and In Vivo Regulation of SRD5A mRNA Expression of Supercritical Carbon Dioxide Extract from Asparagus racemosus Willd. Root as Anti-Sebum and Pore-Minimizing Active Ingredients. Molecules 2022, 27, 1535. https://doi.org/10.3390/ molecules27051535

Academic Editor: Maurizio Battino

Received: 31 December 2021 Accepted: 21 February 2022 Published: 24 February 2022

Publisher's Note: MDPI stays neutral with regard to jurisdictional claims in published maps and institutional affiliations.

Copyright: (C) 2022 by the authors. Licensee MDPI, Basel, Switzerland. This article is an open access article distributed under the terms and conditions of the Creative Commons Attribution (CC BY) license (https:// creativecommons.org/licenses/by/ $4.0 /)$.
1 Department of Pharmaceutical Sciences, Faculty of Pharmacy, Chiang Mai University, Chiang Mai 50200, Thailand; chiranan_k@cmu.ac.th or ckhantham@gmail.com (C.K.); pichchapa_li@cmu.ac.th (P.L.); tanakarn_c@cmu.ac.th (T.C.); pensak.j@cmu.ac.th (P.J.); chuda.c@cmu.ac.th (C.C.)

2 Cluster of Research and Development of Pharmaceutical and Natural Products Innovation for Human or Animal, Chiang Mai University, Chiang Mai 50200, Thailand; sarana.s@cmu.ac.th (S.R.S.); korawan.s@cmu.ac.th (K.S.)

3 Cluster of Agro Bio-Circular-Green Industry, Faculty of Agro-Industry, Chiang Mai University, Chiang Mai 50100, Thailand; pornchai.r@cmu.ac.th (P.R.); jantanasakulwong.k@gmail.com or kittisak.jan@cmu.ac.th (K.J.); yuthana.p@cmu.ac.th (Y.P.)

4 Faculty of Agro-Industry, Chiang Mai University, Chiang Mai 50100, Thailand

5 Department of Animal and Aquatic Sciences, Faculty of Agriculture, Chiang Mai University, Chiang Mai 50200, Thailand; chaiwat_arjin@cmu.ac.th

6 Department of Preventive Medicine and Public Health, Food Science, Toxicology and Forensic Medicine, Faculty of Pharmacy, University of Valencia, 46100 Valencia, Spain; houda.berrada@uv.es (H.B.); francisco.barba@uv.es (F.J.B.)

* Correspondence: warintorn.ruksiri@cmu.ac.th; Tel.: +66-96-269-5354

Abstract: Oily skin from overactive sebaceous glands affects self-confidence and personality. There is report of an association between steroid 5-alpha reductase gene (SRD5A) expression and facial sebum production. There is no study of the effect of Asparagus racemosus Willd. root extract on the regulation of SRD5A mRNA expression and anti-sebum efficacy. This study extracted $A$. racemosus using the supercritical carbon dioxide fluid technique with ethanol and investigated its biological compounds and activities. The $A$. racemosus root extract had a high content of polyphenolic compounds, including quercetin, naringenin, and $p$-coumaric acid, and DPPH scavenging activity comparable to that of the standard L-ascorbic acid. A. racemosus root extract showed not only a significant reduction in SRD5A1 and $S R D 5 A 2$ mRNA expression by about $45.45 \%$ and $90.86 \%$, respectively, but also a reduction in the in vivo anti-sebum efficacy in male volunteers, with significantly superior percentage changes in facial sebum production and a reduction in the percentages of pore area after 15 and 30 days of treatment. It can be concluded that $A$. racemosus root extract with a high content of polyphenol compounds, great antioxidant effects, promising downregulation of SRD5A1 and SRD5A2, and predominant facial sebum reduction and pore-minimizing efficacy could be a candidate for an anti-sebum and pore-minimizing active ingredient to serve in functional cosmetic applications.

Keywords: anti-sebum efficacy; Asparagus racemosus; facial-pore-minimizing efficacy; facial sebum production; 5-alpha reductase enzymes; human volunteer; oily skin; polyphenols; SRD5A; supercritical carbon dioxide fluid extraction

\section{Introduction}

Excessively oily facial skin with greasy, shiny, and large pores causes unpleasant feelings and affects personality. The over-production of facial oil from overactive sebaceous 
glands is the major cause of oily facial skin. Moreover, this skin type is prone to acne and seborrheic dermatitis [1]. Oily or greasy skin is associated with larger pores [2]. Sebum is secreted from sebaceous glands, which are composed of sebaceous follicles [3]. Sebaceous glands are distributed around the face, chest, and upper back [4]. Sebocytes are the predominating cells around sebaceous glands, and they express dihydrotestosterone (DHT) receptors, which influence sebaceous glands' activity in sebum secretion [3,4]. Androgens mainly stimulate sebum production. DHT, a potent androgen, binds to the androgen receptor in the cytoplasm and then translocates to the nucleus for androgen-regulated gene interaction. This signal orderly regulates the proliferation of sebaceous glands, sebum production, and inflammatory cascades [5]. Furthermore, steroid 5-alpha reductase enzymes play a crucial role in converting testosterone into the more potent DHT. The inhibition of steroid 5-alpha reductase gene (SRD5A) expression can decrease the amount of DHT in cells, leading to facial sebum control. Finasteride, a 5-alpha reductase type 2 inhibitor, was approved by the USFDA for benign prostatic hypertrophy and androgenetic alopecia treatment [6]. Dutasteride, a dual type 1 and 25 -alpha reductase inhibitor, was approved for benign prostatic hypertrophy treatment. Both inhibitors are widely used for baldness treatment. However, oral finasteride and dutasteride can inhibit 5-alpha reductase enzymes all over the body, resulting in serious systemic side effects, such as impotence, a decreasing in sexual ability, and ejaculation disorder. Various medicinal plants that can inhibit SRD5A gene expression, such as saw palmetto [7], rice bran, bamboo [8], hemp [9], curcumin [10], and pao pareira [11], have been introduced. Previous studies reported an association between $S R D 5 A$ and facial sebum production [12]. Some cations, especially zinc, have been reported to reduce sebum production in vivo and have been used to treat acne. In vitro assays have indicated that zinc specifically inhibits 5-alpha reductase enzymes. This inhibition may be mediated by both non-competitive inhibition of testosterone binding to 5-alpha reductase enzymes and reduced formation of the NADPH co-factor [13]. Moreover, some medicinal plant extracts, such as saw palmetto, sesame seeds, and argan oil, which have high polyphenolic compounds, have been introduced for facial sebum control [1].

The prescribed medicines for oily skin treatment include topical retinoids, oral isotretinoin, spironolactone, and contraceptives. Most of them have serious side effects, including dry skin, and isotretinoin is contraindicated in pregnancy [4]. Recently, natural products, such as green tea, guava, and L-carnitine topical, have been widely used in antiseborrheic cosmeceutical products [14-16]. Asparagus racemosus Willd., known as Shatavari, is a well-known medicinal plant in the Genus Asparagus, Family Asparagaceae. In Ayurveda, A. racemosus is recommended as an immunoadjuvant and lactation booster [17]. Moreover, most studies have reported various biological activities of $A$. racemosus extract, such as immunomodulatory [18], galactagogue [19], antibacterial [20,21], antifungal [22], and antioxidant $[23,24]$ properties. Additionally, A. racemosus extract has profound antibacterial and antifungal activities against Staphylococcus aureus [20,21] and Malassezia furfur [22], which are related to inflammatory skin diseases, such as seborrheic dermatitis $[25,26]$. Additionally, previous studies have reported a tremendous antioxidant effect of the extract, which resulted in gastric ulcer healing and potential hepatoprotection [23,27]. Interestingly, Himplasia ${ }^{\mathrm{TM}}$ containing Shatavari has been prescribed for benign prostatic hyperplasia, and it was claimed to be an SRD5A1 inhibitor [28]. Several studies have reported that steroidal saponins, isoflavones, flavonoids, and quercetin are the most notable compounds identified in $A$. racemosus root extract $[17,29,30]$. Steroidal saponins mainly play a crucial part in oxytocin-induced contraction blockage [31-33].

Only a few studies have investigated the biological activities and applications of the root extract of $A$. racemosus for functional cosmetic applications [20,22,34], while there are no studies on its anti-sebum efficacy. Therefore, this study aimed to identify the bioactive compounds of $A$. racemosus root extract and determine its effects on antioxidant potential and SRD5A gene regulation. The in vivo efficacy and safety evaluation of the effect of 
A. racemosus extract solution on sebum control and pore-minimizing capabilities allowed us to investigate the potential of $A$. racemosus extract for cosmetic anti-sebum applications.

\section{Results and Discussion}

\subsection{Extraction Yield and Active Compounds of Asparagus racemosus Willd. Root Extract}

The extraction yield from supercritical carbon dioxide $\left(\mathrm{scCO}_{2}\right)$ extraction was $1.08 \%$ (weight of extract/dry weight of plant material). $\mathrm{scCO}_{2}$ was used with ethanol as a cosolvent in this study since ethanol can extract more polar compounds, such as phenolic compounds [35], than $\mathrm{scCO}_{2}$ alone. The results of the polyphenol and flavonoid contents in $A$. racemosus are presented in Table 1 . Six phenolic compounds were found. Quercetin $(3.403 \pm 0.412 \mathrm{mg} / \mathrm{g}$ extract) predominated, followed by naringenin $(0.746 \pm 0.027 \mathrm{mg} / \mathrm{g}$ extract), and $p$-coumaric acid $(0.721 \pm 0.010 \mathrm{mg} / \mathrm{g}$ extract). Caffeic acid $(0.197 \pm 0.018 \mathrm{mg} / \mathrm{g}$ extract), naringin $(0.021 \pm 0.007 \mathrm{mg} / \mathrm{g}$ extract $)$, and rosmarinic acid $(0.012 \pm 0.006 \mathrm{mg} / \mathrm{g}$ extract) were the minor components of the root extract of $A$. racemosus. In addition, previous reports showed the presence of polyphenolic compounds from the aerial parts of A. racemosus $[29,36]$. Interestingly, steroidal saponins, polysaccharides, glycosides, sterols, and triterpenoids were also found in the roots of $A$. racemosus $[24,27,29]$. Novel steroidal saponins, such as shatavarins I-V, shatavarosides A and B, asparinins, asparosides, curillins, and curillosides, have previously been isolated from a root of Shatavari by acetonitrile or methanolic extraction [31-33], and they could be found in the A. racemosus extract from our study.

Table 1. Polyphenol compositions of Asparagus racemosus root extract.

\begin{tabular}{cc}
\hline \multicolumn{3}{c}{ Compositions (mg/g Extract) } \\
\hline Quercetin & $3.403 \pm 0.412$ \\
Naringenin & $0.746 \pm 0.027$ \\
$p$-Coumaric acid & $0.721 \pm 0.010$ \\
Caffeic acid & $0.197 \pm 0.018$ \\
Naringin & $0.021 \pm 0.007$ \\
Rosmarinic acid & $0.012 \pm 0.006$ \\
\hline
\end{tabular}

Each value is expressed as mean $\pm \mathrm{SD}(n=3)$.

\subsection{Antioxidant Effects of Asparagus racemosus Willd. Root Extract Solution}

The antioxidant activity was investigated by DPPH, ABTS radical scavenging methods, and ferrous ion $\left(\mathrm{Fe}^{2+}\right)$ chelating assay. The assay for the capability to scavenge stable free radicals was based on measuring the reduction of DPPH radicals in purple to a reduced form of DPPH in yellow [37]. Subsequently, ABTS radical cations in the blue chromophore disappeared after the acceptance of hydrogen radicals from antioxidant compounds [38]. In addition to the metal chelating activity, an evaluation of chelator could reduce the color intensity of red $\mathrm{Fe}^{2+}$-ferrozine complexes [39]. The antioxidant values observed in the A. racemosus solution were $\mathrm{SC}_{50}$ of $0.502 \pm 0.275 \mathrm{mg} / \mathrm{mL}, \mathrm{SC}_{50}$ of $5.319 \pm 0.327 \mathrm{mg} / \mathrm{mL}$, and $\mathrm{MC}_{50}$ of $1.591 \pm 0.175 \mathrm{mg} / \mathrm{mL}$ against $\mathrm{DPPH}, \mathrm{ABTS}$ radicals, and ferrous ion, respectively (Table 2). These antioxidant capacities of extract via ABTS and chelation methods are lower than Trolox and EDTA standards $(p<0.05)$. Nevertheless, DPPH radical scavenging activity of the extract showed a comparable effect to that of L-ascorbic acid. The antioxidant property of the extract might be due to quercetin, which contains three rings and five hydroxyl groups [40]. The chemical structure of quercetin can trap metal ions, as well as reactive oxygen species [41]. Moreover, topical formulations containing gallic acid and quercetin can reduce skin sebum secretion [42]. It can be concluded that the antioxidant abilities of $A$. racemosus are associated with polyphenol contents. 
Table 2. Antioxidant activities of Asparagus racemosus Willd. root extract solution.

\begin{tabular}{|c|c|c|c|}
\hline $\begin{array}{c}\text { Antioxidant } \\
\text { Activities }\end{array}$ & $\begin{array}{c}\text { DPPH Radical } \\
\text { Scavenging Activity } \\
\left(\mathrm{SC}_{50}, \mathrm{mg} / \mathrm{mL}\right)\end{array}$ & $\begin{array}{c}\text { ABTS Radical } \\
\text { Scavenging Activity } \\
\left(\mathrm{SC}_{50}, \mathrm{mg} / \mathrm{mL}\right)\end{array}$ & $\begin{array}{c}\mathrm{Fe}^{2+} \text { Chelating } \\
\text { Activity } \\
\left(\mathrm{MC}_{50}, \mathrm{mg} / \mathrm{mL}\right)\end{array}$ \\
\hline $\begin{array}{l}\text { A. racemosus Willd. } \\
\text { root extract solution }\end{array}$ & $0.502 \pm 0.275$ & $5.319 \pm 0.327^{\mathrm{a}}$ & $1.591 \pm 0.175^{\mathrm{a}}$ \\
\hline L-ascorbic acid & $0.154 \pm 0.014$ & $0.067 \pm 0.006$ & $\mathrm{Nd}$ \\
\hline Trolox & $\mathrm{Nd}$ & $0.092 \pm 0.003$ & $\mathrm{Nd}$ \\
\hline EDTA & $\mathrm{Nd}$ & $\mathrm{Nd}$ & $0.063 \pm 0.004$ \\
\hline
\end{tabular}

Each value is expressed as mean $\pm \mathrm{SD}(n=3)$; ethylenediaminetetraacetic acid (EDTA); Nd = not determined; $\mathrm{SC}_{50}=$ the concentration providing $50 \%$ scavenging activity $(\mathrm{mg} / \mathrm{mL}) ; \mathrm{MC}_{50}=$ the concentration providing $50 \%$ chelating activity $(\mathrm{mg} / \mathrm{mL})$. A statistical significance in comparison to the control indicated as "a" $(p<0.05)$.

\subsection{Effects of Asparagus racemosus Willd. Root Extract on 5-Alpha Reductase Isoenzymes}

Abnormal sebum production and sebaceous gland enlargement because of excessive androgen levels cause androgen-related skin disorders, such as acne [43]. Testosterone is altered to the most active form of androgen, DHT, by the 5-alpha reductase enzyme [44]. Higher concentrations of the 5 -alpha reductase enzyme in sebaceous glands are associated with acne-prone skin [45]. SRD5A1, expressed as 5-alpha reductase enzyme type 1, can be found in sweat glands, hair follicles, skin, and especially in facial sebaceous glands [46,47]. Furthermore, $S R D 5 A 2$, expressed as 5-alpha reductase enzyme type 2, is found in hair follicles and sebaceous gland ducts [47,48]. However, SRD5A3 is predominantly expressed in prostate cancer cells [49]. Consequently, the effects of SRD5A1 and SRD5A2 suppression may possibly involve the diminishing of excessive sebum production.

In this study, anti-sebum activity was determined by the expression of $S R D 5 A$ isoenzyme assay using the DU-145 cell line. The non-toxic concentration of the A. racemosus extract solution was $10 \mathrm{mg} / \mathrm{mL}$ equivalent to the A. racemosus extract of $0.5 \mathrm{mg} / \mathrm{mL}$. In contrast, the maximum non-toxic concentration of the standard references (finasteride and dutasteride) was $0.1 \mathrm{mg} / \mathrm{mL}$. These concentrations, which showed more than $90 \%$ cell viability [50], were chosen for 5-alpha reductase isoenzyme activity analysis. In this experiment, finasteride, a selective 5-alpha reductase enzyme type 2 inhibitor, and dutasteride, a dual inhibitor of 5-alpha reductase enzymes type 1 and 2 [51], were selected for standard 5 -alpha reductase enzyme inhibitor treatment at a concentration of $0.1 \mathrm{mg} / \mathrm{mL}$. The effects of $A$. racemosus root extract on the mRNA expression of SRD5A isoenzymes compared with the standard 5-alpha reductase inhibitors (finasteride and dutasteride) were demonstrated based on the percentages of $S R D 5 A$ expression (Figure 1). The inhibitory effects of finasteride on $S R D 5 A 1, S R D 5 A 2$, and $S R D 5 A 3$ levels were $68.15 \pm 0.10 \%, 85.27 \pm 1.02 \%$, and $62.50 \pm 2.18 \%$ of control, respectively. In addition, for dutasteride, SRD5A1, SRD5A2, and $S R D 5 A 3 \mathrm{mRNAs}$ were downregulated to $66.19 \pm 0.25 \%, 80.08 \pm 0.16 \%$, and $62.91 \pm 0.09 \%$ of control, respectively. A. racemosus root extract significantly decreased SRD5A1 and SRD5A2 mRNA expression by $45.45 \pm 0.86 \%$ and $90.86 \pm 0.06 \%$ of control, respectively $(p<0.05)$. Zinc has been reported to reduce sebum production in vivo and to inhibit SRD5A via non-competitive inhibition of testosterone binding to $S R D 5 A$ and the decreasing formation of the NADPH cofactor [13]. Many herbal extracts could alleviate androgen-stimulated sebum production from potent $S R D 5 A$ inhibitor activity $[44,52,53]$. Moreover, saw palmetto, sesame seeds, and argan oil, which have high contents of polyphenolic compounds, have been introduced for use in facial sebum control [1]. The high content of polyphenols, quercetin, naringenin, and coumaric acid in the A. racemosus extract solution could exhibit an important role in the reduction of SRD5A1 and SRD5A2 mRNA expression in cells. 


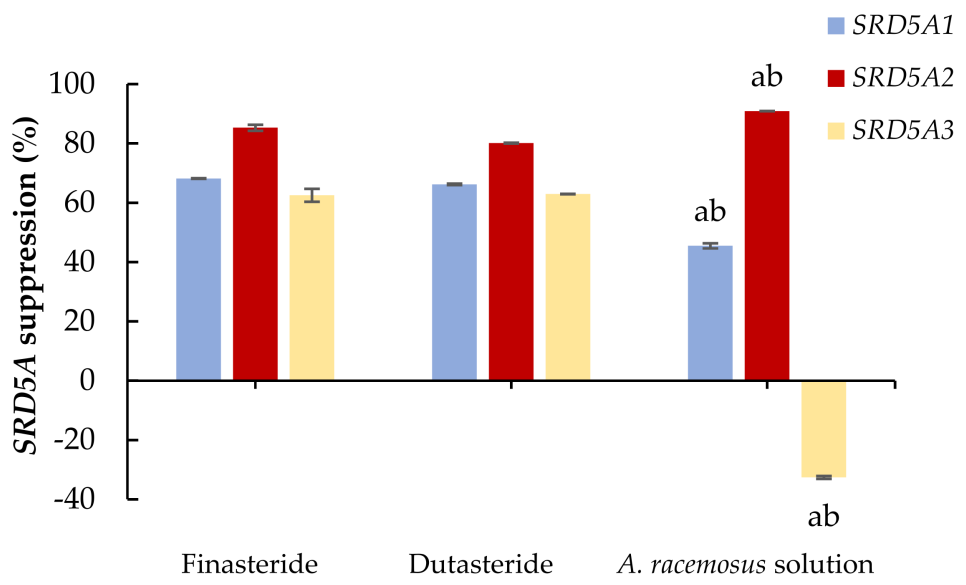

Figure 1. The effects of $0.1 \mathrm{mg} / \mathrm{mL}$ of finasteride and dutasteride, and $0.5 \mathrm{mg} / \mathrm{mL}$ of $A$. racemosus Willd. root extract solution on 5-alpha reductase isoenzymes expression (SRD5A) in human prostate cancer cells. The percentage of SRD5A suppression was compared with the control. Statistical significance in comparison to finasteride and dutasteride is indicated as " $a$ " and " $b$ ", respectively $(p<0.05)$.

\subsection{Effect on Sebum Level and Pore Area in Volunteers}

All volunteers thoroughly accomplished the study protocol. This study compared $5 \% w / v$ of $A$. racemosus root extract (A. racemosus extract solution) with control (5\% of propylene glycol). The facial sebum contents were measured by Sebumeter ${ }^{\circledR}$, which is a widely accepted technique [54]. The results of the percent changes in facial sebum production as anti-sebum efficacy values are illustrated in Figure 2 . The A. racemosus extract solution group showed a higher anti-sebum effect than that of the control group in both groups (male and female) at both time intervals (15 and 30 days of treatment). In particular, after 15 days of application, male volunteers in the A. racemosus extract solution group showed significantly higher anti-sebum efficacy values on the left cheek area than those of the control group $(p<0.05)$, as shown in Figure 2a. The A. racemosus extract solution group demonstrated better anti-sebum efficacy on the left and right cheek areas than that at the forehead area in both groups (male and female). Figure $2 b$ shows that the anti-sebum efficacy of the A. racemosus extract solution group in female volunteers was higher than that in the control group on the right and left cheeks at both time intervals (15 and 30 days of treatment). This might be due to the sensitivity of the sebaceous glands to 5-alpha reductase inhibitors in each specific area. The higher sensitivity of the sebaceous glands on the cheeks to the $A$. racemosus extract than the sensitivity of those on the forehead leads to a lower amount of sebum production on both cheeks. A significant anti-sebum effect was only found in male volunteers. A lower amount of facial sebaceous glands and smaller sebaceous units are found in females [48,55], which may have led to the lower sensitivity of the androgen receptor to anti-androgen compounds and the lower anti-sebum efficacy of female volunteers in this study. A previous study reported that androgen levels in females are lower than in males [56]. The proliferation of sebocytes is stimulated by androgen, resulting in a larger sebaceous gland and a higher level of sebum production in males than in females [56]. These reasons could explain the better response of males over females to the $A$. racemosus root extract.

The percentages of pore areas (large and fine) were evaluated based on facial visualization from VisioFace ${ }^{\circledR}$ CSI software. The percentages of pore area reduction after 15 and 30 days of application were calculated, and they are displayed in Figures 3 and 4 . In the male volunteers, the $A$. racemosus extract solution group showed a significant reduction in both large and fine pore areas on the forehead compared to the control group $(p<0.05)$ at a period of 15 days in Figure 3a, b, respectively. A similar significant reduction in large pore areas on the forehead was found $(p<0.05)$ at a period of 30 days, as shown in Figure 3a. Interestingly, a superior pore size reduction was demonstrated on the forehead area com- 
pared to the cheek area in both large and fine pore areas. Figure 4 shows an example of the before/after 30 days result of the $A$. racemosus extract solution treatment. This male volunteer had an initial large pore area of $3.20 \pm 0.28 \%$ and a fine pore area of $2.48 \pm 0.13 \%$, and after 30 days of treatment, he had a large pore area of $2.15 \pm 0.10 \%$ (large pore area reduction of $32.78 \%$ ) and a fine pore area of $2.28 \pm 0.03 \%$ (fine pore area reduction of $7.18 \%$ ). The lower pore area reduction was shown in the female volunteers, complying with our previous results. Moreover, the treatment time interval to provide a significant anti-sebum effect was 15 days of treatment in the male volunteer group and 30 days of treatment in the female volunteer group. We can conclude that gender affected the anti-sebum activity of the $A$. racemosus extract solution. In the previous study, excessive sebum levels, age, and the male gender affected facial pore size enlargement [56]. Facial pore sizes further play an important role in releasing sebum from sebaceous glands [52]. Androgen is predominantly exerted to the proliferation of sebocytes and sebum production [56,57]. Yoon et al., reported that polyphenolic compounds in medicinal plants played an important role in decreasing sebum production via the anti-lipogenic effect [58]. Previous in vivo studies of Camellia sinensis (green tea), Quercus acutissima bark, and Galdieria sulphuraria extracts, which effectively inhibit 5-alpha reductase activity, showed a reduction in sebum secretion. These effects might be from polyphenol compounds, such as pentagalloyl glucose, eugeniin, and gallic acid $[42,57,59]$.

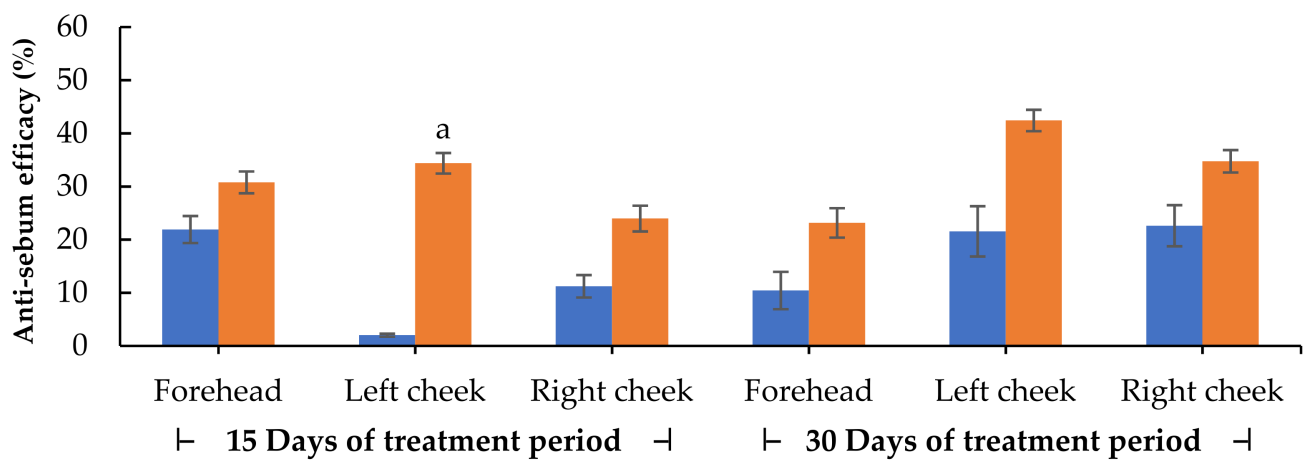

(a) Male

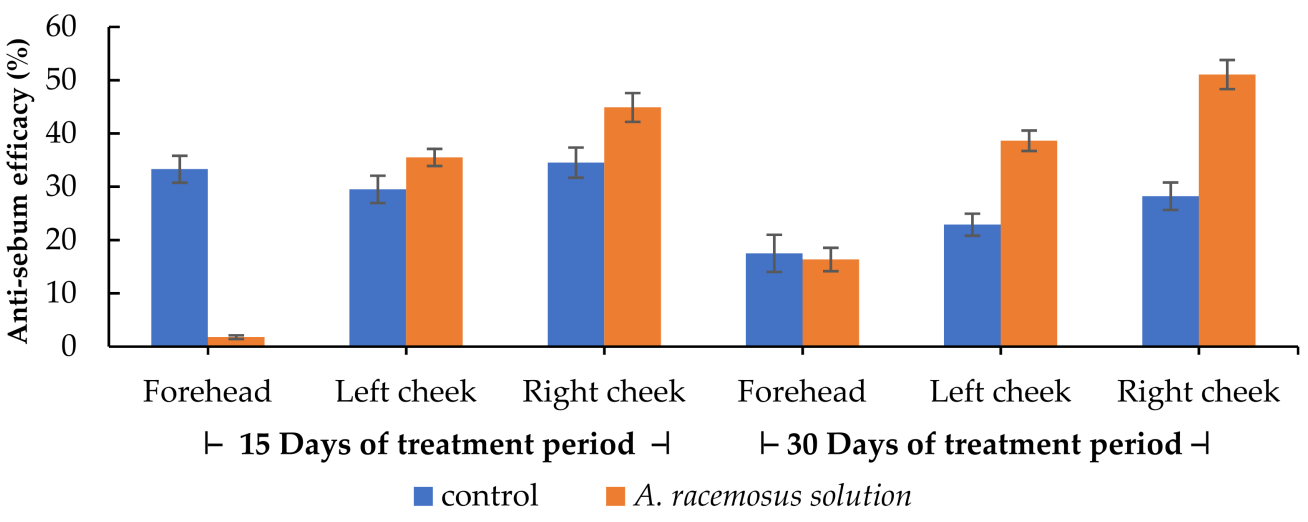

(b) Female

Figure 2. Anti-sebum efficacy of the control (5\% of propylene glycol) and the $5 \%$ of Asparagus racemosus Willd. root extract solution groups on forehead, left cheek, and right cheek. (a) Antisebum efficacy on forehead, left cheek, and right cheek in male volunteers after 15 days and 30 days of treatment periods. (b) Anti-sebum efficacy on forehead, left cheek, and right cheek in female volunteers after 15 days and 30 days of treatment periods. Statistical significance in comparison to the control is indicated as "a" $(p<0.05)$. 


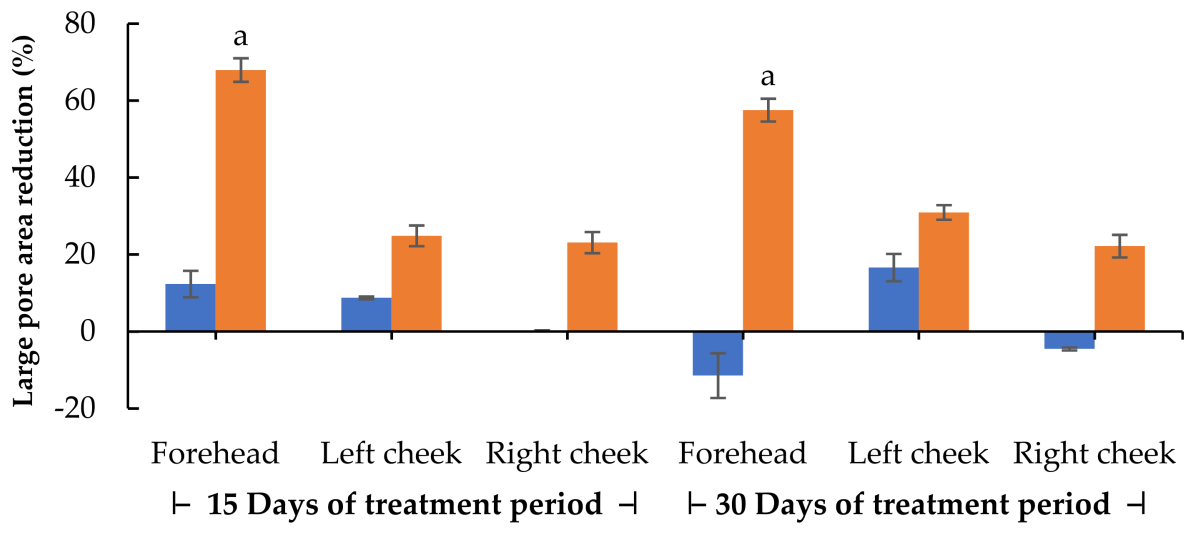

(a) Male

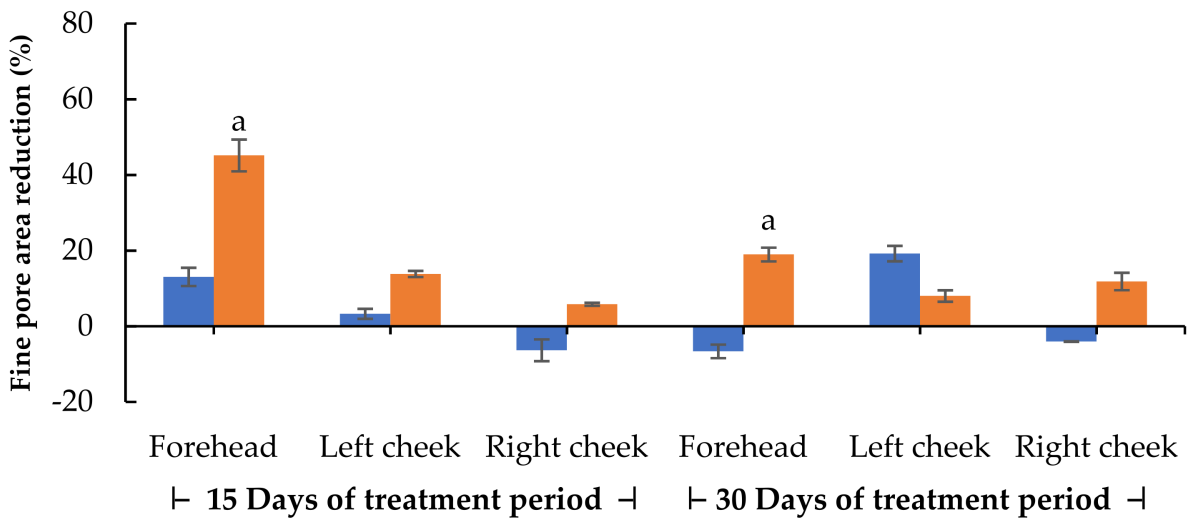

(b) Male

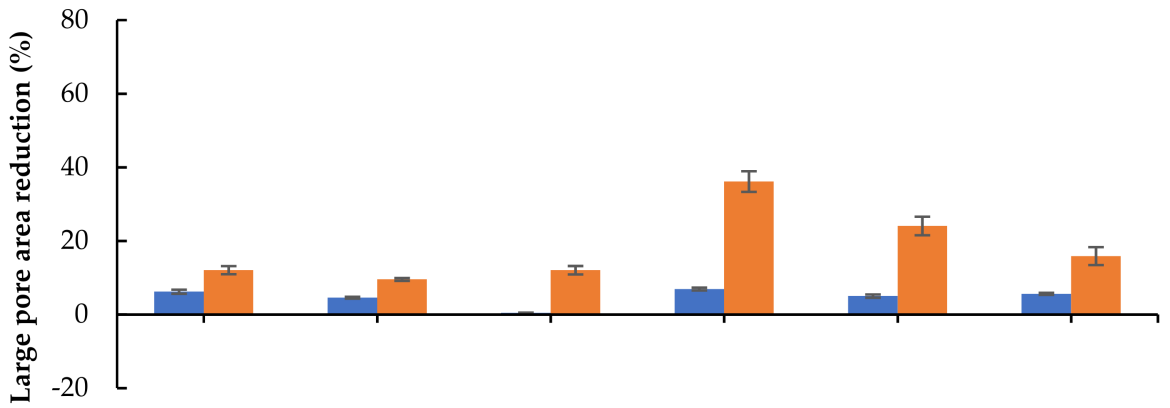

(c) Female

Forehead Left cheek Right cheek Forehead Left cheek Right cheek $\vdash 15$ Days of treatment period $\dashv \quad \vdash 30$ Days of treatment period $\dashv$

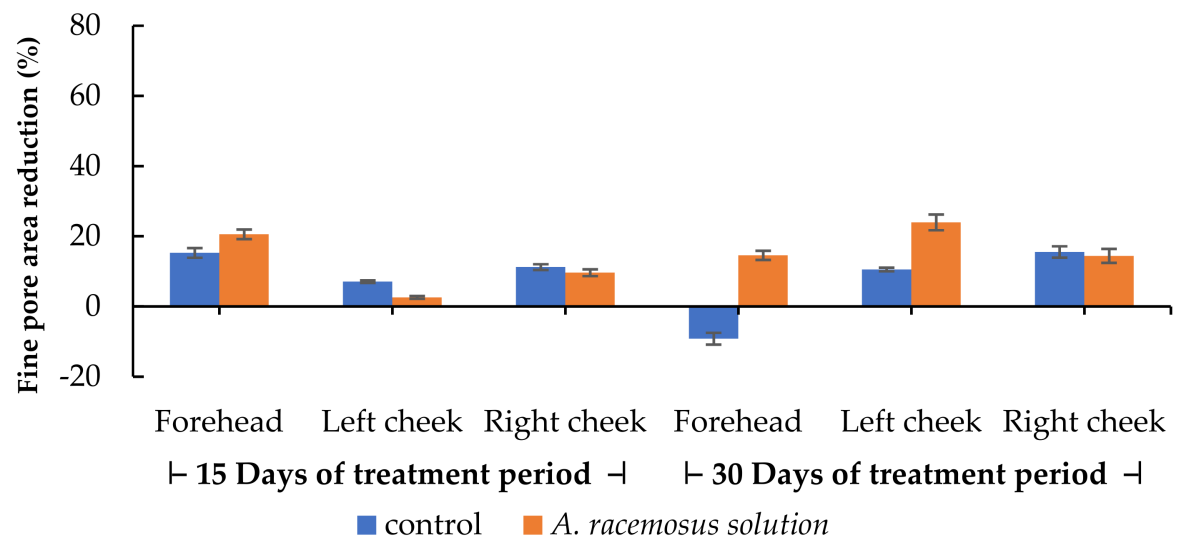

(d) Female

Figure 3. Pore area reduction of the control (5\% of propylene glycol) and the $5 \%$ of Asparagus racemosus Willd. root extract solution groups on forehead, left cheek, and right cheek. (a) Large and (b) fine pore area reduction after 15 days and 30 days of treatment periods in male volunteers. (c) Large and (d) fine pore area reduction after 15 days and 30 days of treatment periods in female volunteers. Statistical significance in comparison to the control is indicated as "a" $(p<0.05)$. 


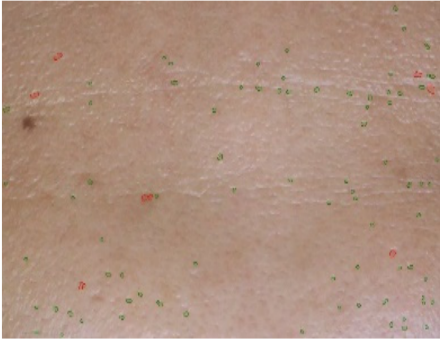

(a)

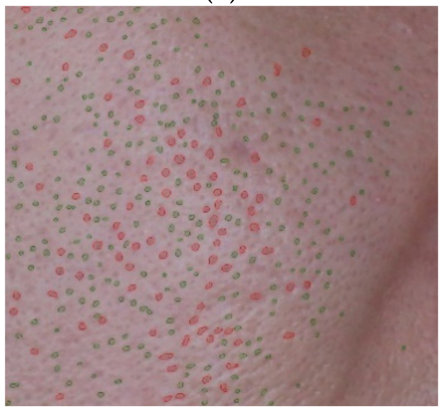

(c)

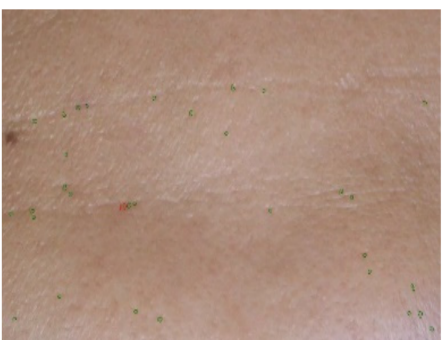

(b)

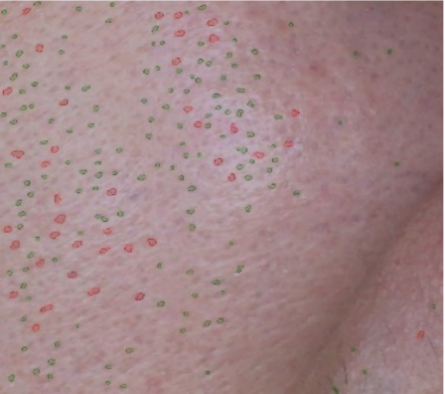

(d)

Figure 4. An example of pore area visualization from the A. racemosus Willd. root extract solution treatment using VisioFace ${ }^{\circledR}$ CSI software (Köln, Germany) (a) before and (b) after 30 days of the extract treatment on forehead; (c) before and (d) after 30 days of the extract treatment on right cheek. Red spots = large pores; green spots = fine pores.

Moreover, the activity of the 5-alpha reductase enzyme and the production of testosterone and DHT in oily skin are upregulated. As a result, 5-alpha reductase is the major enzyme involved in the conversion of testosterone to the more potent DHT $[13,46]$. The topical application of $5 \%$ of the A. racemosus root extract solution with a high content of polyphenol compounds showed a superior anti-sebum potential and pore reduction effect in male volunteers. These results may imply that $A$. racemosus root extract could downregulate SRD5A1 and SRD5A2 expression, thereby decreasing sebum production and providing the pore-minimizing ability of the in vivo test.

For a subjective assessment, the results of the volunteers' satisfaction of product characteristics, skin tolerance, and efficacy are shown in Figure 5. All volunteers from the A. racemosus extract groups stated that the extract solution had great potential to decease facial grease, minimize pore sizes, and provide smoother skin. However, the unique odor of the $A$. racemosus extract was not satisfactory.

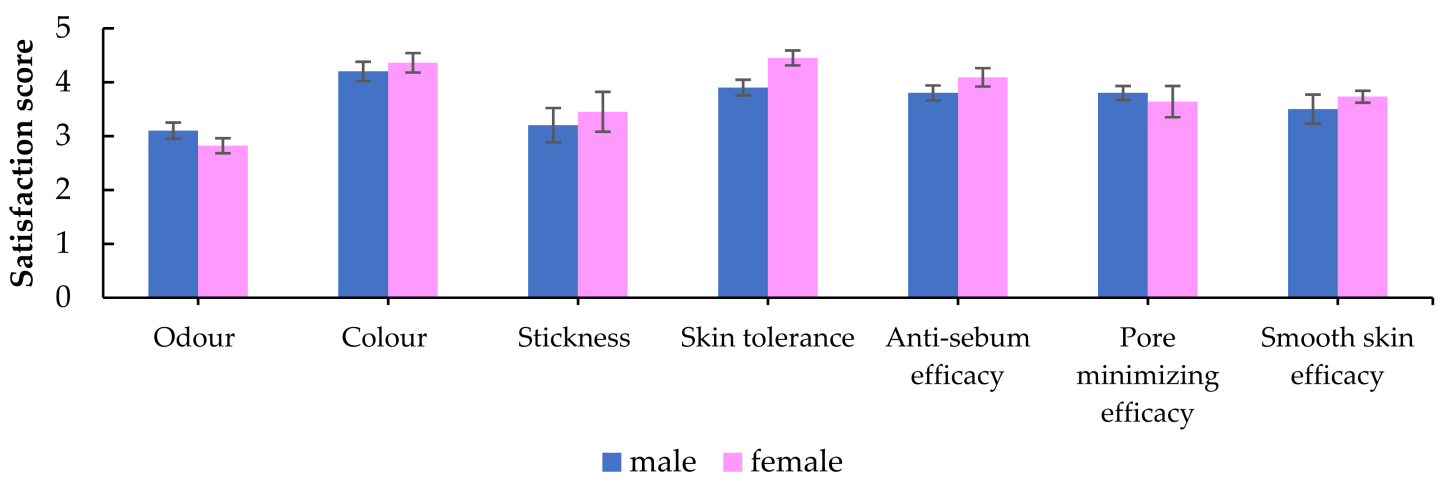

Figure 5. Volunteer satisfaction of the characteristics, tolerance, and efficacy of A. racemosus Willd. root extract solution (male $n=10$, female $n=12$ ). 


\section{Materials and Methods}

\subsection{Chemicals and Reagents}

Finasteride and dutasteride were purchased from Wuhan W\&Z Biotech (Wuhan, China). Trypsin, Roswell Park Memorial Institute medium (RPMI-1640), fetal bovine serum (FBS), penicillin, and streptomycin were obtained from Gibco (Thermo Fisher Scientific, Waltham, MA, USA). 2,2-Diphenyl-1-picrylhydrazyl (DPPH), 2,2'-azino-bis (ethylbenzthiazoline-6-sulfonic acid (ABTS), 3-(2-yyridyl)-5,6-diphenyl-1,2,4-triazine- $4^{\prime}, 4^{\prime \prime}$ disulfonic acid sodium salt (ferrozine), iron (II) chloride tetrahydrate $\left(\mathrm{FeCl}_{2} \cdot 4 \mathrm{H}_{2} \mathrm{O}\right)$, L-ascorbic acid, Trolox, ethylenediaminetetraacetic acid (EDTA), and sulforhodamine B (SRB) were obtained from Sigma Chemical (St. Louis, MO, USA). Agarose gel, Tris base, and 50X Tris/acetic acid/EDTA (TAE) were obtained from Bio-Rad Laboratories (Hercules, CA, USA). Ethanol, acetic acid, trichloroacetic acid, and other chemical substances were obtained from RCI Labscan (Bangkok, Thailand). All other chemical substances were of analytical grade.

\subsection{Preparation of Sample}

The dried root of Shatavari (Asparagus racemosus Willd.) was provided by Bangkok Lab \& Cosmetic Co., Ltd. (Ratchaburi, Thailand). Plant material was prepared by supercritical carbon dioxide $\left(\mathrm{scCO}_{2}\right)$ fluid extraction following a patent-pending process. Dried and crushed $A$. racemosus roots $(1 \mathrm{~kg}$ ) were placed into the extractor (Guangzhou Gongcheng Digital Science Technology, Guangzhou, China) operating at $50{ }^{\circ} \mathrm{C}$ and $30 \mathrm{MPa}$ for $1 \mathrm{~h}$, with $1 \mathrm{~L}$ of $95 \%(v / v)$ ethanol as a cosolvent. The extract solution was concentrated using a rotary evaporator (Hei-VAP value, Heidolph, Schwabach, Germany) at temperature up to $50{ }^{\circ} \mathrm{C}$. The $A$. racemosus extract was stored at $4{ }^{\circ} \mathrm{C}$ until further use for analysis. The $A$. racemosus extract was diluted in the propylene glycol at the concentration of $5 \%$ $w / v$ (A. racemosus extract solution) for the antioxidant, 5-alpha reductase isoenzymes, and in vivo efficacy test.

\subsection{Analysis of Phenolic Compounds in Asparagus racemosus Willd. Root Extract by Liquid Chromatography-Mass Spectrometry (LC-MS)}

The Agilent 1260 Infinity II series (Agilent Tech., Santa Clara, CA, USA) was connected to an electrospray ionization (ESI) quadrupole mass spectrometry 6130 equipped with a degasser, binary pump, column oven, and thermostatted autosampler, and analysis was performed according to our previously reported method [60]. The reversed-phase C18 analytical column $(250 \times 4.6 \mathrm{~mm}, 4.6 \mathrm{~mm}, 5 \mu \mathrm{m}$ (Restek Corporation, Bellefonte, PA, USA) was used for separation. A column was kept at $30^{\circ} \mathrm{C}$, and the flow rate was $0.5 \mathrm{~mL} / \mathrm{min}$. Then, $5 \mu \mathrm{L}$ of the sample volume $(10 \mathrm{mg} / \mathrm{mL}$ of sample was dissolved in ethanol and filtrated through a $0.45 \mu \mathrm{m}$ syringe filter) was injected. Gradient elution was performed using 5\% formic acid as solvent $\mathrm{A}$ and acetonitrile: $\mathrm{H}_{2} \mathrm{O}$ : formic acid (85:10:5) as solvent B. A linear gradient was performed as follows: 0-8 min, 80\% A; 8-24 min, decreased A to $25 \%$; 24-28 $\mathrm{min}, 25 \% \mathrm{~A} ; 28-34 \mathrm{~min}$, increased A to $70 \%$; 34-36 min, increased A to $80 \%$; 36-45 $\mathrm{min}, 80 \%$ A. Mass analysis of compounds was performed using negative ion monitoring (SIM). Nitrogen was used as a drying gas, and the program was performed as follows: flow rate, $12 \mathrm{~L} / \mathrm{min}$; drying gas temperature, $350{ }^{\circ} \mathrm{C}$; nebulizer pressure, $60 \mathrm{psi}$; capillary voltage, $3000 \mathrm{~V}$; fragmentor voltage, $70 \mathrm{~V}$; and full-scan spectra from 100 to 1200 m/z with 250 ms/spectrum. OpenLab software (Agilent Tech., Santa Clara, CA, USA) was used for spectra analysis. The list of phenolic compounds, the limit of detection, and the limit of quantification are provided in Table S1.

\subsection{Antioxidant Activities Analysis}

\subsubsection{DPPH Radical Scavenging Activity}

The DPPH assay was performed using the previous protocol with slight modifications [50]. The result was compared to that of L-ascorbic acid. The sample was diluted by distillated water in the range of $0.01-10 \mathrm{mg} / \mathrm{mL}$. Briefly, $50 \mu \mathrm{L}$ of the sample was re- 
acted with $50 \mu \mathrm{L}$ of $0.1 \mathrm{mM}$ DPPH solution, which was freshly prepared in ethanol. The mixtures were incubated at room temperature in the dark for $30 \mathrm{~min}$. The absorbance was measured at $517 \mathrm{~nm}$ against a blank (ethanol), using a microplate reader (EZ Read 2000, Biochrom, Holliston, MA, USA). The percentages of the DPPH radical scavenging activity were calculated by Equation (1), where $\mathrm{Abs}_{\text {Control }}$ is the absorbance of the DPPH solution, and $\mathrm{Abs}_{\text {Sample }}$ is the absorbance of the DPPH radicals that reacted with the sample:

$$
\mathrm{DPPH} \text { radical scavenging activity }(\%)=\frac{\mathrm{Abs}_{\text {Control }}-\mathrm{Abs}_{\text {Sample }}}{\mathrm{Abs}_{\text {Control }}} \times 100 \text {. }
$$

The concentration providing 50\% scavenging activity $\left(\mathrm{SC}_{50}\right)(\mathrm{mg} / \mathrm{mL})$ was obtained from the linear relationship between the concentration of the samples and the percentages of the DPPH radical scavenging activity.

\subsubsection{ABTS Radical Scavenging Activity}

The ABTS assay was evaluated according to the previous method with some modifications [50]. The assay was based on ABTS radical scavenging ability in comparison to that of Trolox and L-ascorbic acid in the range of $0.01-10 \mathrm{mg} / \mathrm{mL}$. The ABTS stock solutions were prepared by placing $7 \mathrm{mM}$ of ABTS radical solution in distilled water reacted with $2.45 \mathrm{mM}$ of potassium persulfate solution, and they were stored at room temperature in the dark for 12-16 h. Then, the ABTS working solution was diluted to obtain an absorbance of 0.7-0.9 at $734 \mathrm{~nm}$ with distilled water using the microplate reader (EZ Read 2000, Biochrom, Holliston, MA, USA). The sample $(25 \mu \mathrm{L})$ was reacted with $200 \mu \mathrm{L}$ of ABTS solution for $10 \mathrm{~min}$. The percentages of the ABTS radical scavenging activity were calculated by Equation (2), where $\mathrm{Abs}_{\text {Control }}$ is the absorbance of the ABTS solution, and Abs Sample $_{\text {is }}$ the absorbance of the ABTS radicals that reacted with the sample:

$$
\text { ABTS radical scavenging activity }(\%)=\frac{\mathrm{Abs}_{\text {Control }}-\mathrm{Abs}_{\text {Sample }}}{\mathrm{Abs}_{\text {Control }}} \times 100 \text {. }
$$

The concentration providing $50 \%$ scavenging activity $\left(\mathrm{MC}_{50}\right)(\mathrm{mg} / \mathrm{mL})$ was obtained from the linear relationship between the different concentrations of the samples and the percentages of the ABTS radical scavenging activity.

\subsubsection{Metal Chelating Activity}

Iron chelating activity was analyzed by a previously reported method [60]. Briefly, $50 \mu \mathrm{L}$ of $5 \mathrm{mM}$ ferrozine was mixed with $50 \mu \mathrm{L}$ of $\mathrm{FeCl}_{2} \cdot 4 \mathrm{H}_{2} \mathrm{O}$ solution. The sample was diluted with distillated water to use concentrations ranging from 0.01 to $10 \mathrm{mg} / \mathrm{mL}$. Then, $100 \mu \mathrm{L}$ of the sample reacted with the solution of ferrozine-Fe ${ }^{2+}$ complex for $30 \mathrm{~min}$ at room temperature. EDTA was used as a standard. The absorbance of ferrozine-Fe ${ }^{2+}$ complex was measured at $562 \mathrm{~nm}$ using the microplate reader (EZ Read 2000, Biochrom, Holliston, USA). The percentages of metal chelating activity were calculated by Equation (3), where $\mathrm{Abs}_{\mathrm{Control}}$ is the absorbance of the ferrozine-Fe ${ }^{2+}$ complex, and Abs Sample is the absorbance of the ferrozine-Fe ${ }^{2+}$ complex reacted with the sample:

$$
\text { Metal chelating activity }(\%)=\frac{\mathrm{Abs}_{\text {Control }}-\mathrm{Abs}_{\text {Sample }}}{\mathrm{Abs}_{\text {Control }}} \times 100 \text {. }
$$

The concentration providing $50 \%$ chelating activity $\left(\mathrm{MC}_{50}\right)(\mathrm{mg} / \mathrm{mL})$ was obtained from the linear relationship between the different concentrations of the samples and the ferrous scavenging activity. 


\subsection{5-Alpha Reductase Isoenzyme Activity Analysis \\ 3.5.1. Cell Culture}

DU-145 human prostate cancer cells were obtained from the American Type Culture Collection (Rockville, MD, USA). DU-145 cells were cultured in RPMI-1640 and supplemented with $10 \%(v / v)$ FBS, $100 \mu \mathrm{g} / \mathrm{mL}$ of streptomycin, and $100 \mathrm{unit} / \mathrm{mL}$ of penicillin. The cells were maintained in a temperature-controlled $\left(37^{\circ} \mathrm{C}\right)$ and humidified incubator containing $5 \% \mathrm{CO}_{2}$ (CCL-050B-8, Esco ${ }^{\circledR}$, Singapore).

\subsubsection{Determination of Cell Viability}

The non-cytotoxic concentration of the samples on DU-145 cells was determined by sulforhodamine B (SRB) assay, as previously described [50]. Human prostate cancer cells $\left(1 \times 10^{5}\right.$ cells $\left./ \mathrm{mL}\right)$ were cultured in 96 -well plates for $24 \mathrm{~h}$ at $37^{\circ} \mathrm{C}$ and $5 \% \mathrm{CO}_{2}$. The cells were tested with the samples in the range of $0.0001-10 \mathrm{mg} / \mathrm{mL}$ for another $24 \mathrm{~h}$. After incubation, the adherent cells were fixed in situ by 50\% trichloroacetic acid and dyed with $0.04 \%$ SRB solution, which was prepared in $1 \%$ acetic acid. The bound dye was solubilized, and the absorbance was measured at $515 \mathrm{~nm}$ using the microplate reader (EZ Read 2000, Biochrom, Holliston, MA, USA). The percentages of cell viability were

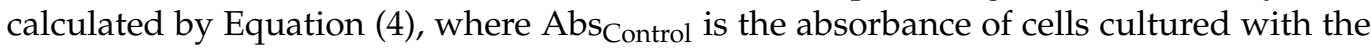
medium without supplementation, $\mathrm{Abs}_{\text {Blank }}$ is the absorbance of cells treated with the solvent, and $\mathrm{Abs}_{\text {Sample }}$ is the absorbance of cells treated with the sample:

$$
\text { Cell viability }(\%)=\frac{\mathrm{Abs}_{\text {Sample }}-\mathrm{Abs}_{\text {Blank }}}{\mathrm{Abs}_{\text {Control }}-\mathrm{Abs}_{\text {Blank }}} \times 100
$$

3.5.3. RNA Extraction and Semi-Quantitative Reverse Transcription Polymerase Chain Reaction (RT-PCR) Analysis

The regulation of $S R D 5 A$ gene expression was tested as previously described [61]. Initially, DU-145 cells were treated with the samples for $24 \mathrm{~h}$. Total RNA was extracted using the NucleoSpin ${ }^{\circledR}$ RNA isolation kit (Macherey-Nagel, Duren, Germany). The extracted RNA was quantified by Qubit 4 fluorometer (Invitrogen, Carlsbad, CA, USA) and Qubit ${ }^{\mathrm{TM}}$ RNA HS Assay Kit (Invitrogen). The complementary DNA (cDNA) was generated from the RT-PCR Quick Master Mix (Toyobo, Osaka, Japan) according to the instructions of the manufacturer. Gene-specific primers were used as follows: SRD5A1, F: 5' AGCCATTGTGCAGTGTATGC-3' and R: 5'-AGCCTCCCCTTGGTATTTTG-3'; SRD5A2, F: $5^{\prime}$-TGAATACCCTGATGGGTGG-3' ${ }^{\prime}$ and R: $5^{\prime}$-CAAGCCACCTTGTGGAATC- $3^{\prime}$; SRD5A3, F: $5^{\prime}$-TCCTTCTTTGCCCAAACATC- ${ }^{\prime}$ and R: $5^{\prime}$-CTGATGCTCTCCCTTTACGC- $3^{\prime}$; the reference gene (glyceraldehyde 3-phosphate dehydrogenase (GAPDH)), F: 5'-GGAAGGTGAAGGTCGGAGTC- $3^{\prime}$ and R: 5'-CTCAGCCTTGACGGTGCCATG-3'. The expression of SRD5A was calculated relative to GAPDH expression. The percentages of $S R D 5 A$ suppression were calculated by Equation (5), where $\mathrm{RE}_{\mathrm{Control}}$ is the expression of $S R D 5 A$ genes on untreated cells relative to GAPDH value, and $\mathrm{RE}_{\text {Sample }}$ is the expression of $S R D 5 A$ genes on treated cells relative to GAPDH value:

$$
S R D 5 A \text { suppression }(\%)=\frac{R E_{\text {Control }}-R_{\text {Sample }}}{R E_{\text {Control }}} \times 100 \text {. }
$$

\subsection{Efficacy Evaluation}

\subsubsection{Study Population}

The study was approved by the Ethics Committee of Chiang Mai University (approval number $002 / 2564 / F$ ), and informed consent was obtained from volunteers. Thai healthy volunteers, 20 males and 22 females, who were aged 18-60 years [62] and had mean sebum values of more than $220 \mu \mathrm{g} / \mathrm{cm}^{2}$ on forehead and $180 \mu \mathrm{g} / \mathrm{cm}^{2}$ on cheeks, measured using Sebumeter $^{\circledR}$ (SM815; Courage + Khazaka Electronic GmbH, Cologne, Germany) according to the guidelines of the manufacturer, were enrolled in this randomized, double- 
blinded, placebo-controlled study. The subjects were allocated to either the control group (propylene glycol) $(n=21)$ or the active group (A. racemosus root extract) $(n=21)$. Exclusion criteria included pregnancy, breastfeeding, irritation to cosmetic products, use of topical corticosteroids and/or vitamin A derivative and/or oil control products, and current dermatological pathologies.

\subsubsection{Measurement of Anti-Sebum Efficacy and Pore Area Reduction}

The efficacy evaluation was determined by following the modified method [16]. The skin tests were carried out in a room of $20 \pm 1{ }^{\circ} \mathrm{C}$ and $40-60 \%$ relative humidity. The subjects were allowed to rest in the room for 30 min before randomization to apply 1 pump of the $5 \%$ of propylene glycol or $5 \%$ of $A$. racemosus root extract twice a day. The facial sebum contents and full-face photography at baseline and at 15 and 30 days of treatment period were performed using Sebumeter ${ }^{\circledR}$ and VisioFace ${ }^{\circledR}$ 1000D Camera, respectively, with inbuilt Complete Skin Investigation (CSI) analysis software (Courage + Khazaka Electronic $\mathrm{GmbH}$, Cologne, Germany). A subject withdrew from the study after skin irritation at the application site. The facial sebum values of forehead, left cheek, and right cheek were acquired from Sebumeter ${ }^{\circledR}$ measurement. The percentages of anti-sebum efficacy were calculated by Equation (6), where St is the sebum values at the time interval, and S0 is the sebum values at baseline:

$$
\text { Anti }- \text { sebum efficacy }(\%)=\frac{\mathrm{St}}{\mathrm{S} 0} \times 100 \text {. }
$$

The percentages of pore area at baseline and at different times of treatment period were obtained from VisioFace ${ }^{\circledR}$ reports. The percentages of pore area reduction were calculated by Equation (7), where Pt is the percentages of the pore area at the time interval, and P0 is the percentages of the pore area at baseline:

$$
\text { Pore area reduction }(\%)=100-\left(\frac{\mathrm{Pt}}{\mathrm{P} 0} \times 100\right)
$$

\subsubsection{Self-Assessment}

A subjective evaluation questionnaire regarding the product characteristics (odor, color, and stickiness), tolerance, and efficacy was evaluated by grading scores on a 1 to 5 scale ( 1 is the minimum and 5 is the maximum score of satisfaction) after 30 days of twice-daily application.

\subsection{Statistical Analysis}

All experiments were performed in at least triplicate for each test. Data are expressed as means \pm standard deviation (SD). One-way ANOVA, followed by LSD's post hoc test, was used to analyze the significant differences using SPSS 23.0 software (SPSS Inc., Chicago, IL, USA). The efficacy determinations were analyzed with an independent $t$ test. A value of $p<0.05$ is considered statistically significant.

\section{Conclusions}

Asparagus racemosus Willd. root was extracted using the supercritical $\mathrm{CO}_{2}$ technique with ethanol as a cosolvent. The $A$. racemosus root extract had a high content of polyphenolic compounds, including quercetin, naringenin, and coumaric acid, providing DPPH radical scavenging activity comparable to that of standard L-ascorbic acid. The anti-sebum efficacy of the $A$. racemosus extract solution was determined via in vitro and in vivo assays. An in vitro assay of the mRNA expression of $S R D 5 A$ isoenzymes (types 1-3) was conducted and compared with that of the standard 5-alpha reductase enzyme inhibitors (finasteride and dutasteride). The 5-alpha reductase enzyme inhibitors showed an association with the decrease in facial sebum production. Not only did A. racemosus root extract show a significant reduction in SRD5A1 and SRD5A2 mRNA expression by $45.45 \pm 0.86 \%$ and 
$90.86 \pm 0.06 \%$, but it also showed a reduction in in vivo anti-sebum efficacy in male volunteers in the percentage changes in facial sebum production and percentages of pore area reduction after 15 and 30 days of treatment. This anti-sebum effect was not shown in the female volunteers; i.e., there was a lower percentage of changes in facial sebum production and lower percentages of pore area reduction after treatment in the female group. However, the number of volunteers should be increased in future studies. From the results of this study, it can be concluded that $A$. racemosus root extract, with its high content of polyphenol compounds, promising antioxidant effects, downregulation of SRD5A1 and SRD5A2, and predominant facial sebum reduction and facial pore minimizing efficacy, could be a candidate as an anti-sebum active ingredient to serve in functional cosmetic applications.

Supplementary Materials: The following are available online, Table S1: Precision of the method, linearity data for calibration curves, and retention time (RT) of reference phenolic compounds studied.

Author Contributions: Conceptualization, K.S. and W.R.; methodology, W.R.; software, S.R.S., C.A. and K.S.; validation, C.A. and K.S.; formal analysis, P.J.; investigation, C.K., T.C. and P.L.; resources, W.R.; data curation, P.L. and W.R.; writing—original draft preparation, P.L. and W.R.; writing—review and editing, P.L., C.C., P.R., K.J., Y.P., H.B., F.J.B. and W.R.; supervision, W.R.; project administration, W.R.; funding acquisition, W.R. All authors have read and agreed to the published version of the manuscript.

Funding: This research project is supported by the funding number 104/2564 from the Industrial Research and Technology Capacity Development Program (IRTC) from Science and Technology Park (STeP), Chiang Mai University, Northern Science Park, Thailand, and partially supported by Chiang Mai University.

Institutional Review Board Statement: The study was conducted according to the guidelines of the Declaration of Helsinki and approved by the Ethics Committee of Chiang Mai University (approval number 002/2564/F, Approved Date 12 July 2021).

Informed Consent Statement: Informed consent was obtained from all subjects involved in the study.

Data Availability Statement: The data presented in this study are available on request from the corresponding author.

Acknowledgments: The authors are grateful to Bangkok Lab \& Cosmetic Co., Ltd. for the plant sample. We would like to thank the Science and Technology Park (STeP), Chiang Mai University, Northern Science Park, Thailand, and Chiang Mai University for the financial support.

Conflicts of Interest: The authors declare no conflict of interest.

Sample Availability: Not available.

\section{References}

1. Dobrev, H. Clinical and instrumental study of the efficacy of a new sebum control cream. J. Cosmet. Dermatol. 2007, 6, 113-118. [CrossRef]

2. Mohiuddin, A. A comprehensive review of acne vulgaris. J. Clin. Pharm. 2019, 1, 17-45. [CrossRef]

3. Shamloul, G.; Khachemoune, A. An updated review of the sebaceous gland and its role in health and diseases Part 1: Embryology, evolution, structure, and function of sebaceous glands. Dermatol. Ther. 2021, 34, e14695. [CrossRef] [PubMed]

4. Endly, D.C.; Miller, R.A. Oily skin: A review of treatment options. J. Clin. Aesthet. Dermatol. 2017, 10, 49. [PubMed]

5. Santhosh, P.; George, M. Clascoterone: A new topical anti-androgen for acne management. Int. J. Dermatol. 2021, 60, 1561-1565. [CrossRef]

6. Irwig, M.S. Is there a role for $5 \alpha$-reductase inhibitors in transgender individuals? Andrology 2020, 9, 1729-1731. [CrossRef]

7. Pais, P. Potency of a novel saw palmetto ethanol extract, SPET-085, for inhibition of $5 \alpha$-reductase II. Adv. Ther. 2010, 27, 555-563. [CrossRef]

8. Song, K.H.; Seo, C.-S.; Yang, W.-K.; Gu, H.-O.; Kim, K.-J.; Kim, S.-H. Extracts of Phyllostachys pubescens leaves represses human steroid 5-alpha reductase Type 2 promoter activity in BHP-1 cells and ameliorates testosterone-induced benign prostatic hyperplasia in rat model. Nutrients 2021, 13, 884. [CrossRef]

9. Manosroi, A.; Chankhampan, C.; Kietthanakorn, B.O.; Ruksiriwanich, W.; Chaikul, P.; Boonpisuttinant, K.; Sainakham, M.; Manosroi, W.; Tangjai, T.; Manosroi, J. Pharmaceutical and cosmeceutical biological activities of hemp (Cannabis sativa L. var. sativa) leaf and seed extracts. Chiang Mai J. Sci. 2019, 46, 180-195. 
10. Kim, J.Y.; Lee, J.Y.; Yoon, H.-G.; Kim, Y.; Jun, W.; Hwang, K.T.; Cha, M.S.; Lee, Y.-H. Inhibitory effect of Curcuma longa L. extracts on 5-alpha reductase II activity. J. Korean Soc. Food Sci. Nutr. 2014, 43, 318-322. [CrossRef]

11. Liu, J.; Fang, T.; Li, M.; Song, Y.; Li, J.; Xue, Z.; Li, J.; Bu, D.; Liu, W.; Zeng, Q. Pao pereira extract attenuates testosterone-induced benign prostatic hyperplasia in rats by inhibiting $5 \alpha$-reductase. Sci. Rep. 2019, 9, 19703. [CrossRef] [PubMed]

12. Rocha, M.A.; Bagatin, E. Adult-onset acne: Prevalence, impact, and management challenges. Clin. Cosmet. Investig. Dermatol. 2018, 11, 59. [CrossRef] [PubMed]

13. Azzouni, F.; Godoy, A.; Li, Y.; Mohler, J. The 5 alpha-reductase isozyme family: A review of basic biology and their role in human diseases. Adv. Urol. 2011, 2012, 530121. [CrossRef] [PubMed]

14. Saric, S.; Notay, M.; Sivamani, R.K. Green tea and other tea polyphenols: Effects on sebum production and acne vulgaris. Antioxidants 2017, 6, 2. [CrossRef] [PubMed]

15. Peirano, R.I.; Hamann, T.; Düsing, H.J.; Akhiani, M.; Koop, U.; Schmidt-Rose, T.; Wenck, H. Topically applied l-carnitine effectively reduces sebum secretion in human skin. J. Cosmet. Dermatol. 2012, 11, 30-36. [CrossRef]

16. Pongsakornpaisan, P.; Lourith, N.; Kanlayavattanakul, M. Anti-sebum efficacy of guava toner: A split-face, randomized, single-blind placebo-controlled study. J. Cosmet. Dermatol. 2019, 18, 1737-1741. [CrossRef]

17. Alok, S.; Jain, S.K.; Verma, A.; Kumar, M.; Mahor, A.; Sabharwal, M. Plant profile, phytochemistry and pharmacology of Asparagus racemosus (Shatavari): A review. Asian Pac. J. Trop. Dis. 2013, 3, 242-251. [CrossRef]

18. Gautam, M.; Saha, S.; Bani, S.; Kaul, A.; Mishra, S.; Patil, D.; Satti, N.; Suri, K.; Gairola, S.; Suresh, K.; et al. Immunomodulatory activity of Asparagus racemosus on systemic Th1/Th2 immunity: Implications for immunoadjuvant potential. J. Ethnopharmacol. 2009, 121, 241-247. [CrossRef] [PubMed]

19. Gupta, M.; Shaw, B. A double-blind randomized clinical trial for evaluation of galactogogue activity of Asparagus racemosus Willd Iran J. Pharm. Res. 2011, 10, 167. [PubMed]

20. Mandal, S.C.; Nandy, A.; Pal, M.; Saha, B. Evaluation of antibacterial activity of Asparagus racemosus Willd. root. Phytother. Res. 2000, 14, 118-119. [CrossRef]

21. Patel, L.; Patel, R. Antimicrobial activity of Asparagus racemosus wild from leaf extracts-A medicinal plant. Int. J. Sci. Res. 2013, 3 , 2250-3153.

22. Onlom, C.; Khanthawong, S.; Waranuch, N.; Ingkaninan, K. In vitro anti-Malassezia activity and potential use in anti-dandruff formulation of Asparagus racemosus. Int. J. Cosmet. Sci. 2014, 36, 74-78. [CrossRef] [PubMed]

23. Bhatnagar, M.; Sisodia, S.S.; Bhatnagar, R. Antiulcer and antioxidant activity of Asparagus racemosus Willd and Withania somnifera Dunal in rats. Ann. N. Y. Acad. Sci. 2005, 1056, 261-278. [CrossRef] [PubMed]

24. Selvaraj, K.; Sivakumar, G.; Pillai, A.A.; Veeraraghavan, V.P.; Bolla, S.R.; Veeraraghavan, G.R.; Rengasamy, G.; Joseph, J.P.; Janardhana, P. Phytochemical screening, HPTLC fingerprinting and In vitro antioxidant activity of root extract of Asparagus racemosus. Pharmacogn. J. 2019, 11, 818-823. [CrossRef]

25. Tamer, F.; Yuksel, M.E.; Sarifakioglu, E.; Karabag, Y. Staphylococcus aureus is the most common bacterial agent of the skin flora of patients with seborrheic dermatitis. Dermatol. Pract. Concept. 2018, 8, 80. [CrossRef] [PubMed]

26. Nakabayashi, A.; Sei, Y.; Guillot, J. Identification of Malassezia species isolated from patients with seborrhoeic dermatitis, atopic dermatitis, pityriasis versicolor and normal subjects. Med. Mycol. 2000, 38, 337-341. [CrossRef]

27. Acharya, S.; Acharya, N.; Bhangale, J.; Shah, S.; Pandya, S. Antioxidant and hepatoprotective action of Asparagus racemosus Willd. root extracts. Indian J. Exp. Biol. 2012, 50, 795-801.

28. Shrivastava, A.; Gupta, V.B. Various treatment options for benign prostatic hyperplasia: A current update. J. Midlife Health 2012, 3,10 .

29. Singh, R.; Geetanjali. Asparagus racemosus: A review on its phytochemical and therapeutic potential. Nat. Prod. Res. 2016, 30, 1896-1908

30. Joshi, R.K. Asparagus racemosus (Shatawari), phytoconstituents and medicinal importance, future source of economy by cultivation in Uttrakhand: A review. Int. J. Herb. Med. 2016, 4, 18-21.

31. Hayes, P.Y.; Jahidin, A.H.; Lehmann, R.; Penman, K.; Kitching, W.; De Voss, J.J. Asparinins, asparosides, curillins, curillosides and shavatarins: Structural clarification with the isolation of shatavarin V, a new steroidal saponin from the root of Asparagus racemosus. Tetrahedron Lett. 2006, 47, 8683-8687. [CrossRef]

32. Hayes, P.Y.; Jahidin, A.H.; Lehmann, R.; Penman, K.; Kitching, W.; De Voss, J.J. Structural revision of shatavarins I and IV, the major components from the roots of Asparagus racemosus. Tetrahedron Lett. 2006, 47, 6965-6969. [CrossRef]

33. Sharma, U.; Saini, R.; Kumar, N.; Singh, B. Steroidal saponins from Asparagus racemosus. Chem. Pharm. Bull. 2009, 57, 890-893. [CrossRef] [PubMed]

34. Rungsanga, T.; Tuntijarukornb, P.; Ingkaninanc, K.; Viyocha, J. Stability and clinical effectiveness of emulsion containing Asparagus racemosus root extract. Sci. Asia 2015, 41, 236-245. [CrossRef]

35. Reátegui, J.L.P.; da Fonseca Machado, A.P.; Barbero, G.F.; Rezende, C.A.; Martínez, J. Extraction of antioxidant compounds from blackberry (Rubus sp.) bagasse using supercritical $\mathrm{CO}_{2}$ assisted by ultrasound. J. Supercrit. 2014, 94, 223-233. [CrossRef]

36. Ashraf, G.J.; Das, P.; Dua, T.K.; Paul, P.; Nandi, G.; Sahu, R. High-performance thin-layer chromatography based approach for bioassay and ATR-FTIR spectroscopy for the evaluation of antioxidant compounds from Asparagus racemosus Willd. aerial parts. Biomed. Chromatogr. 2021, 35, e5230. [CrossRef] 
37. Meng, L.; Lozano, Y.F.; Gaydou, E.M.; Li, B. Antioxidant activities of polyphenols extracted from Perilla frutescens varieties. Molecules 2009, 14, 133-140. [CrossRef]

38. Jasprica, I.; Bojic, M.; Mornar, A.; Besic, E.; Bucan, K.; Medic-Saric, M. Evaluation of antioxidative activity of croatian propolis samples using DPPH' and ABTS ${ }^{+}$stable free radical assays. Molecules 2007, 12, 1006-1021. [CrossRef]

39. Karamać, M. Chelation of Cu (II), Zn (II), and Fe (II) by tannin constituents of selected edible nuts. Int. J. Mol. Sci. 2009, 10, 5485-5497. [CrossRef]

40. Moalin, M.; Van Strijdonck, G.P.; Beckers, M.; Hagemen, G.J.; Borm, P.J.; Bast, A.; Haenen, G.R. A planar conformation and the hydroxyl groups in the $\mathrm{B}$ and $\mathrm{C}$ rings play a pivotal role in the antioxidant capacity of quercetin and quercetin derivatives. Molecules 2011, 16, 9636-9650. [CrossRef]

41. Bhuiyan, M.N.I.; Mitsuhashi, S.; Sigetomi, K.; Ubukata, M. Quercetin inhibits advanced glycation end product formation via chelating metal ions, trapping methylglyoxal, and trapping reactive oxygen species. Biosci. Biotechnol. Biochem. 2017, 81, 882-890. [CrossRef] [PubMed]

42. Koseki, J.; Matsumoto, T.; Matsubara, Y.; Tsuchiya, K.; Mizuhara, Y.; Sekiguchi, K.; Nishimura, H.; Watanabe, J.; Kaneko, A.; Hattori, T. Inhibition of rat $5 \alpha$-reductase activity and testosterone-induced sebum synthesis in hamster sebocytes by an extract of Quercus acutissima cortex. Evid.-Based Complement. Altern. Med. 2015, 2015, 853846. [CrossRef] [PubMed]

43. Dhurat, R.; Shukla, D.; Lim, R.K.; Wambier, C.G.; Goren, A. Spironolactone in adolescent acne vulgaris. Dermatol. Ther. 2021, 34, e14680. [CrossRef] [PubMed]

44. Kim, M.; Yin, J.; Hwang, I.H.; Park, D.H.; Lee, E.K.; Kim, M.J.; Lee, M.W. Anti-acne vulgaris effects of pedunculagin from the leaves of Quercus mongolica by anti-inflammatory activity and $5 \alpha$-reductase inhibition. Molecules 2020, 25, 2154. [CrossRef]

45. Crocco, E.I.; Bonifácio, E.B.; Facchini, G.; da Silva, G.H.; da Silva, M.S.; Pinheiro, A.L.T.A.; Avelar, P.V.F.; Eberlin, S. Modulation of skin androgenesis and sebum production by a dermocosmetic formulation. J. Cosmet. Dermatol. 2021, 20, 360-365. [CrossRef]

46. Makrantonaki, E.; Ganceviciene, R.; Zouboulis, C.C. An update on the role of the sebaceous gland in the pathogenesis of acne. Derm.-Endocrinol. 2011, 3, 41-49. [CrossRef]

47. Skałba, P.; Dabkowska-Huć, A.; Kazimierczak, W.; Samojedny, A.; Samojedny, M.; Chełmicki, Z. Content of 5-alpha-reductase (type 1 and type 2) mRNA in dermal papillae from the lower abdominal region in women with hirsutism. Clin. Exp. Dermatol. 2006, 31, 564-570. [CrossRef]

48. Zouboulis, C.C.; Degitz, K. Androgen action on human skin-from basic research to clinical significance. Exp. Dermatol. 2004, 13, 5-10. [CrossRef]

49. Uemura, M.; Tamura, K.; Chung, S.; Honma, S.; Okuyama, A.; Nakamura, Y.; Nakagawa, H. Novel 5 $\alpha$-steroid reductase (SRD5A3, type-3) is overexpressed in hormone-refractory prostate cancer. Cancer Sci. 2008, 99, 81-86. [CrossRef]

50. Ruksiriwanich, W.; Khantham, C.; Sringarm, K.; Sommano, S.; Jantrawut, P. Depigmented Centella asiatica extraction by pretreated with supercritical carbon dioxide fluid for wound healing application. Processes 2020, 8, 277. [CrossRef]

51. Hazlehurst, J.M.; Oprescu, A.I.; Nikolaou, N.; Di Guida, R.; Grinbergs, A.E.; Davies, N.P.; Flintham, R.B.; Armstrong, M.J.; Taylor, A.E.; Hughes, B.A. Dual- $5 \alpha$-reductase inhibition promotes hepatic lipid accumulation in man. J. Clin. Endocrinol. Metab. 2016, 101, 103-113. [CrossRef] [PubMed]

52. Laneri, S.; Dini, I.; Tito, A.; Di Lorenzo, R.; Bimonte, M.; Tortora, A.; Zappelli, C.; Angelillo, M.; Bernardi, A.; Sacchi, A. Plant cell culture extract of Cirsium eriophorum with skin pore refiner activity by modulating sebum production and inflammatory response. Phytother. Res. 2021, 35, 530-540. [CrossRef] [PubMed]

53. Yin, J.; Hwang, I.H.; Lee, M.W. Anti-acne vulgaris effect including skin barrier improvement and $5 \alpha$-reductase inhibition by tellimagrandin I from Carpinus tschonoskii. BMC Complement. Altern. Med. 2019, 19, 323. [CrossRef]

54. Meetham, P.; Kanlayavattanakul, M.; Lourith, N. Development and clinical efficacy evaluation of anti-greasy green tea tonner on facial skin. Rev. Bras. Farmacogn. 2018, 28, 214-217. [CrossRef]

55. Sugawara, T.; Nakagawa, N.; Shimizu, N.; Hirai, N.; Saijo, Y.; Sakai, S. Gender-and age-related differences in facial sebaceous glands in Asian skin, as observed by non-invasive analysis using three-dimensional ultrasound microscopy. Skin Res. Technol. 2019, 25, 347-354. [CrossRef] [PubMed]

56. Roh, M.; Han, M.; Kim, D.; Chung, K. Sebum output as a factor contributing to the size of facial pores. Br. J. Dermatol. 2006, 155, 890-894. [CrossRef]

57. Mahmood, T.; Akhtar, N.; Khan, B.A.; Khan, H.M.S.; Saeed, T. Outcomes of 3\% green tea emulsion on skin sebum production in male volunteers. Bosn. J. Basic Med. Sci. 2010, 10, 260. [CrossRef]

58. Yoon, J.Y.; Kwon, H.H.; Min, S.U.; Thiboutot, D.M.; Suh, D.H. Epigallocatechin-3-gallate improves acne in humans by modulating intracellular molecular targets and inhibiting P. acnes. J. Investig. Dermatol. 2013, 133, 429-440. [CrossRef]

59. Bimonte, M.; De Lucia, A.; Carola, A.; Tito, A.; Buono, S.; Langellotti, A. Galdieria sulphuraria relieves oily and seborrheic skin by inhibiting the $5 \alpha$-reductase expression in skin cells and reducing sebum production in vivo. Trichol. Cosmetol. Open J. 2016, 1, 11-18. [CrossRef]

60. Nazir, Y.; Linsaenkart, P.; Khantham, C.; Chaitep, T.; Jantrawut, P.; Chittasupho, C.; Rachtanapun, P.; Jantanasakulwong, K.; Phimolsiripol, Y.; Sommano, S.R.; et al. High efficiency in vitro wound healing of Dictyophora indusiata extracts via antiInflammatory and collagen stimulating (MMP-2 inhibition) mechanisms. J. Fungi 2021, 7, 1100. [CrossRef] 
61. Khantham, C.; Yooin, W.; Sringarm, K.; Sommano, S.R.; Jiranusornkul, S.; Carmona, F.D.; Nimlamool, W.; Jantrawut, P.; Rachtanapun, P.; Ruksiriwanich, W. E5-alpha reductase gene expression of Thai rice bran extracts and molecular dynamics study on SRD5A2. Biology 2021, 10, 319. [CrossRef] [PubMed]

62. Delsin, S.; Mercurio, D.; Fossa, M.; Maia Campos, P. Clinical efficacy of dermocosmetic formulations containing Spirulina extract on young and mature skin: Effects on the skin hydrolipidic barrier and structural properties. Clin. Pharmacol. Biopharm. $2015,4,2$. 